DOE/RL-2014-38

Revision 0

PNNL-23471

\title{
100-OL-1 Operable Unit Field Portable X-Ray Fluorescence (XRF) Analyzer Pilot Study Plan
}

Prepared for the U.S. Department of Energy

Assistant Secretary for Environmental Management

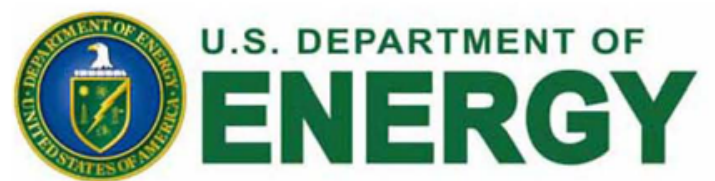

Richland Operations

P.O. Box 550

Richland, Washington 99352 

DOE/RL-2014-38

Revision 0

PNNL-23471

\section{0-OL-1 Operable Unit Field Portable X-Ray Fluorescence (XRF) Analyzer Pilot Study Plan}

Date Published

July 2014

Prepared for the U.S. Department of Energy

Assistant Secretary for Environmental Management

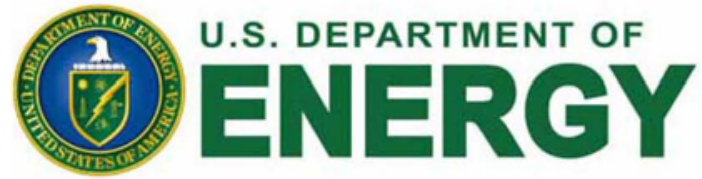

Richland Operations

Office

P.O. Box 550

Richland, Washington 99352 
DOE/RL-2014-38

Revision 0

PNNL-23471

TRADEMARK DISCLAIMER

Reference herein to any specific commercial product, process, or service by trade name, trademark, manufacturer, or otherwise, does not necessarily constitute or imply its endorsement, recommendation, or favoring by the United States Government or any agency thereof or its contractors or subcontractors.

This report has been reproduced from the best available copy. 


\section{Summary}

A pilot study is being conducted to support the approval of the Remedial Investigation/Feasibility Study (RI/FS) Work Plan to evaluate the 100-OL-1 Operable Unit (OU) pre-Hanford orchard lands. Based on comments received by the U.S. Environmental Protection Agency (EPA) and Washington State Department of Ecology, the pilot study will evaluate the use of field portable X-ray fluorescence (XRF) spectrometry measurements for evaluating lead and arsenic concentrations on the soil surface as an indicator of past use of lead arsenate pesticide residue in the OU. The work will be performed in the field during the summer of 2014, and assist in the planning for the characterization activities in the RI/FS. The pilot study will demonstrate for the RI/FS Work Plan that collecting the XRF data is sufficient and defensible for:

- Determining the nature and extent of lead and arsenic in surface soils in selected decision units

- Evaluating the sampling approach to optimize sampling for the RI (e.g., estimating the variability across the surface soil in a decision unit)

- Evaluating the appropriate size for a decision unit within the OU (minimum and maximum acreage)

- Determining which types of decision units could be carried forward in the FS (e.g., areas in 1943 aerial imagery that are known to be orchards vs. areas that appear to be agricultural lands).

In addition, the pilot study will provide cost estimates for sampling activities and information for evaluating the cultural resources review in the RI. The pilot study will support the revisions needed for approval of the 100-OL-1 OU RI/FS Work Plan. 



\section{Acronyms and Abbreviations}

PNNL-23471

$\begin{array}{ll}\text { DOE } & \text { U.S. Department of Energy } \\ \text { EPA } & \text { U.S. Environmental Protection Agency } \\ \text { FS } & \text { feasibility study } \\ \text { GIS } & \text { geographic information system } \\ \text { GPS } & \text { Global Positioning System } \\ \text { HASQARD } & \text { Hanford Analytical Services Quality Assurance Requirements Documents } \\ \text { ICP-MS } & \text { inductively coupled plasma mass spectroscopy } \\ \text { OU } & \text { operable unit } \\ \text { RI } & \text { remedial investigation } \\ \text { RL } & \text { Richland Operations Office } \\ \text { WIDS } & \text { Waste Information Data System } \\ \text { XRF } & \text { X-ray fluorescence }\end{array}$





\section{Contents}

Summary. iii

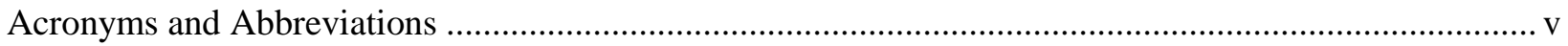

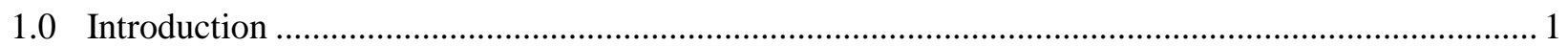

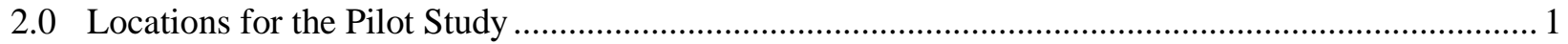

3.0 Screening Criteria for Evaluating Lead and Arsenic in Surface Soil ............................................... 3

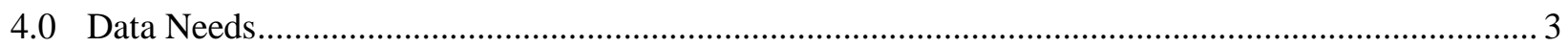

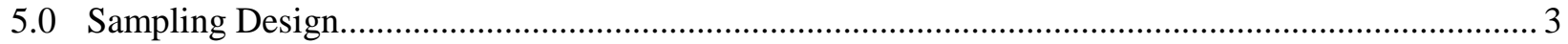

6.0 Analytical Method for the Field Portable XRF Spectroscopy …...................................................... 4

7.0 Quality Assurance and Quality Control Elements ..................................................................... 4



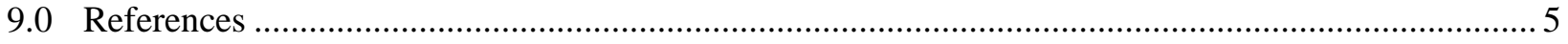

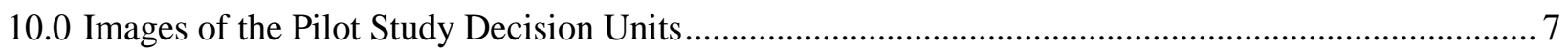

\section{Figures}

Figure 1. Pilot Study Decision Units (yellow fill) within the 100-OL-1 Operable Unit............................. 7

Figure 2. 1943 Aerial Imagery with OL-14 Decision Unit (green outline) ................................................ 8

Figure 3. Current Aerial Imagery with OL-14 Decision Unit and Select Locations for Sampling

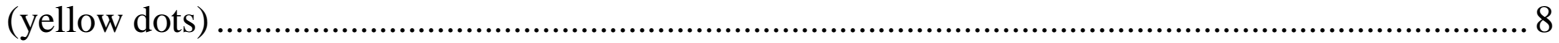

Figure 4. 1943 Aerial Imagery with OL-32 Decision Unit (green outline) ............................................. 9

Figure 5. Current Aerial Imagery with OL-32 Decision Unit and Select Locations for Sampling



Figure 6. 1943 Aerial Imagery with OL-FR2-1 Decision Unit (green outline) ....................................... 10

Figure 7. Current Aerial Imagery with OL-FR2-1 Decision Unit and Select Locations for

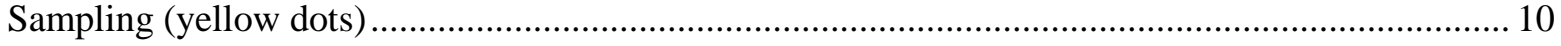

Figure 8. 1943 Aerial Imagery with OL-IU6-4 Decision Unit (green outline)........................................ 11

Figure 9. Current Aerial Imagery with OL-IU6-4 Decision Unit and Select Locations for Sampling (yellow dots)

\section{Tables}

Table 1. Background Information for the Pilot Study Decision Units 2 



\subsection{Introduction}

A pilot study is being conducted to support the approval of the Remedial Investigation/Feasibility Study (RI/FS) Work Plan to evaluate the 100-OL-1 Operable Unit (OU) pre-Hanford orchard lands. Based on comments received by the U.S. Environmental Protection Agency (EPA) and Washington State Department of Ecology, the pilot study will evaluate the use of field portable X-ray fluorescence (XRF) spectrometry measurements for evaluating lead and arsenic concentrations on the soil surface as an indicator of past use of lead arsenate pesticide residue in the OU. The work will be performed in the field during the summer of 2014, and assist in the planning for the characterization activities in the RI/FS. The pilot study will demonstrate for the RI/FS Work Plan that collecting the XRF data is sufficient and defensible for:

- Determining the nature and extent of lead and arsenic in surface soils in selected decision units

- Evaluating the sampling approach to optimize sampling for the RI (e.g., estimating the variability across the surface soil in a decision unit)

- Evaluating the appropriate size for a decision unit within the OU (minimum and maximum acreage)

- Determining which types of decision units could be carried forward in FS (e.g., areas in 1943 aerial imagery that are known to be orchards vs. areas that appear to be agricultural lands)

In addition, the pilot study will provide cost estimates for sampling activities and information for evaluating the cultural resources review in the RI. The pilot study will support the revisions needed for approval of the 100-OL-1 OU RI/FS Work Plan.

This pilot study plan is divided into the following areas:

- Locations for the pilot study

- Screening criteria for evaluating lead and arsenic in surface soil

- Data needs

- Sampling design

- Analytical method for the field portable XRF spectroscopy

- Quality assurance and quality control elements

- Data assessment for final report

\subsection{Locations for the Pilot Study}

Table 1 identifies the four locations within 100-OL-1 OU selected for the pilot study evaluation (see Figure 1 in section 10.0 for an aerial photograph of the locations). The sites are decision units identified in the draft Work Plan (DOE-RL 2013). The following discusses the differences in the pilot study decision units and how these decision units represent the breadth of conditions representing the 100-OL-1 OU. 
DOE/RL-2014-38

Revision 0

PNNL-23471

Table 1. Background Information for the Pilot Study Decision Units

\begin{tabular}{cccccc}
\hline $\begin{array}{c}\text { Decision } \\
\text { Unit ID }\end{array}$ & $\begin{array}{c}\text { Acreage for } \\
\text { Evaluation }\end{array}$ & $\begin{array}{c}\text { Presence of } \\
\text { Trees in 1943 } \\
\text { Aerial Imagery? }\end{array}$ & $\begin{array}{c}\text { Evidence of Soil } \\
\text { Disturbance Since } \\
\text { 1943? }\end{array}$ & $\begin{array}{c}\text { WIDS Site within } \\
\text { Decision Unit } \\
\text { Boundaries? }\end{array}$ & Previously Sampled? \\
\hline OL-14 & 46.4 & Yes & Yes & Yes & Yes \\
OL-32 & 28.7 & Yes & No & No & $\begin{array}{c}\text { Yes } \\
\text { (Yokel and Delistraty } \\
\text { 2003; Delistraty and } \\
\text { Yokel 2011) }\end{array}$ \\
OL-FR2-1 & 48.0 & No & Yes & Yes & Yes \\
OL-IU6-4 & 250.6 & Yes & Yes & Yes & Yes \\
\hline \multicolumn{7}{l}{ WIDS is Waste Information Data System. }
\end{tabular}

OL-14 is located to the northwest of $100 \mathrm{H}$ Area, near the Columbia River (Figure 2 and Figure 3). Historical records indicate that this area was a commercial orchard operation prior to March 1943, and later was a military site. Cleanup actions in this area focused on soil contamination from military activities. Currently, there are several locations with wells for pump and treat activities. Past sampling activities indicate the presence of lead concentrations ranging from background (10 mg/kg) to greater than $500 \mathrm{mg} / \mathrm{kg}$. The U.S. Department of Energy Richland Operations Office (DOE-RL) Cultural Resources Program has cleared a small region of OL-14 for soil sampling. In the designated area for soil sampling, soil will be collected to prepare the site-specific calibration standards and confirmatory samples (see discussion below on quality control).

OL-32 is located south of $100 \mathrm{H}$ Area (Figure 4 and Figure 5). The area remains relatively undisturbed; tree stumps and branches from past orchards are still evident at this location. There are no signs of soil disturbances since orchard operations ceased, and there are no known waste sites in this decision unit. Yokel and Delistraty (2003) as well as Delistraty and Yokel (2011) discuss previous sampling efforts in this location. No soil samples will be collected in OL-32 because the DOE-RL Cultural Resources Program has not cleared this area for soil disturbances.

OL-FR2-1 is located in the southeast corner of 100 F Area (Figure 6 and Figure 7). The 1943 aerial imagery does not show trees similar to other known orchard locations, but does show other agricultural activities. The decision unit has been disturbed by activities associated with the operation of $100 \mathrm{~F}$ reactor (e.g., burial grounds and process sewer), and the decision unit overlaps with the 100-FR-2 OU. No soil samples will be collected in OL-FR2-1 because the DOE-RL Cultural Resources Program has not cleared this area for soil disturbances.

OL-IU6-4 is located north of the Hanford townsite (Figure 8 and Figure 9). This is the largest of the decision units for the pilot study. The 1941-1943 aerial imagery show that most of this decision unit was used for orchards and other agricultural activities. Several areas of the decision unit were disturbed by past agricultural activities and remediated as part of the River Corridor activities (less than 5 acres), e.g., the removal of the Buckholdt Ranch toilet pits and several barrels of lime sulfur. The Critical Mass Laboratory Complex from the Cold War era was also located in this decision unit and is currently in the interim closeout process. The DOE-RL Cultural Resources Program has cleared a small region of OLIU6-4 for soil sampling. In the designated area for soil sampling, soil will be collected to prepare the sitespecific calibration standards and confirmatory samples (see discussion below on quality control). 
DOE/RL-2014-38

Revision 0

PNNL-23471

\subsection{Screening Criteria for Evaluating Lead and Arsenic in Surface Soil}

The XRF spectroscopy results of lead and arsenic concentrations in surface soil within each pilot study decision unit will be compared to the screening level of $250 \mathrm{mg} / \mathrm{kg}$ lead and $20 \mathrm{mg} / \mathrm{kg}$ arsenic.

\subsection{Data Needs}

The following are the data needs to perform the field work for the pilot study:

- Soil samples will be collected to serve as "site-specific calibration standards" for empirical calibration of the XRF instrument (EPA 2007a). The soil samples will be collected from the OL-14 and OLIU6-4 decision units, in areas cleared by the DOE-RL Cultural Resources Program for soil collection. At the beginning of the project, XRF will be used to identify soil in several locations at a range around the screening criteria. The screening criteria are $250 \mathrm{mg} / \mathrm{kg}$ lead and $20 \mathrm{mg} / \mathrm{kg}$ arsenic. The soil will be returned to the laboratory, homogenized, and the lead and arsenic concentrations of the soil sample will be confirmed by inductively coupled plasma mass spectroscopy (ICP-MS). The set of soil samples will be used daily in the field to confirm calibration of the XRF instrument, along with the calibration procedure recommended by the manufacturer (internal calibration) and verification with certified, standard reference material. The XRF instrument will also be re-calibrated in the field if there is a change in weather (e.g., precipitation).

- Confirmatory soil samples will be collected in designated regions of OL-14 and OL-IU6-4, where soil sampling has been cleared by the DOE-RL Cultural Resources Program. Sixteen soil samples will be collected and analyzed by ICP-MS (EPA 2007a and b). The soil collected for confirmatory samples will be approximately $10 \mathrm{~g}$, scraped from a $10 \mathrm{~cm}^{2}$ area co-located with the five replicate XRF readings for that location.

- An ecological compliance review will be completed prior to field work. The review will identify areas of concern for the field samplers to avoid during field characterization activities.

\subsection{Sampling Design}

The probability-based sampling design provides the best approach for evaluating the nature and extent of lead and arsenic soil concentrations within the pilot study decision units (EPA 2002; DOE-RL 2013). A probabilistic sampling design, compared to a judgmental sampling design, allows for statistical inferences about the sampled population and the data obtained from the sampled units. This design meets the approach for evaluating the average concentration of lead and arsenic in a decision unit and compares the average to the $95^{\text {th }}$ percentile upper confidence limit to the $250 \mathrm{mg} / \mathrm{kg}$ lead and $20 \mathrm{mg} / \mathrm{kg}$ arsenic screening levels. The layout of the sampling locations within a decision unit will be selected using a random-start, systematic-grid-sampling design. The Visual Sampling Plan tool (Matzke et al. 2010) will identify the sample locations prior to field activities (see images of the pilot study locations in section 
DOE/RL-2014-38

Revision 0

PNNL-23471

10.0). Sample locations within decision units will be relocated at the discretion of the field team if the location has been disturbed or has substantial vegetation. Examples of disturbances that will require relocation of the field measurement point are layback areas from remediation activities (that may not be included in the GIS information for WIDS), groundwater well pads, and abandoned materials from past settler activities. Field samplers will relocate the measurements to the closest area that has not been disturbed and record the GPS location.

There will be 40 surface soil samples analyzed within each pilot study decision unit. This number of samples is based on 1) a review of the lead measurements in soil across the 100-OL-1 OU, the background of lead in soil, and the screening criteria for evaluating lead contamination; and 2) a review of past results of soil analyses in the 100-OL-1 OU and a best estimate for providing sufficient information to allow statistical evaluation of the field results and meet the screening criteria for the pilot study. Based on the variability of arsenic, 26 surface soil samples (DOE-RL 2013) are needed. Additional measurements will allow further statistical analyses for the RI sampling design.

\subsection{Analytical Method for the Field Portable XRF Spectroscopy}

The surface soil within each pilot study decision unit will be measured in situ for lead and arsenic concentrations using a Niton XL3t 950 GOLDD+ field portable XRF analyzer (Thermo Scientific). To measure with XRF, the "measurement location is cleared of any significant vegetation, such as large clumps of grass, and is scuffed or otherwise leveled to provide a flat surface on which to place the instrument window,” per EPA Science and Ecosystem Support Division Procedure 107-R2 (EPA 2011). The area will also be clear of any roots.

XRF measurements will be performed according to the manufacturer's guide for soil analysis. An optimization study prior to the field sampling will determine the optimum measurement time and number of replicate measurements for the lower levels of detection, precision, and accuracy necessary to differentiate between the soil background concentrations $(10.2 \mathrm{mg} / \mathrm{kg}$ lead and $6.5 \mathrm{mg} / \mathrm{kg}$ arsenic) and the screening level for the screening criteria (250 mg/kg lead and $20 \mathrm{mg} / \mathrm{kg}$ arsenic).

\subsection{Quality Assurance and Quality Control Elements}

The field sampling activities will be based on the quality assurance project plan in the Remedial Investigation/Feasibility Study Work Plan to Evaluate the 100 OL-1 Operable Unit Pre Hanford Orchard Lands (DOE-RL 2013). Specific elements of the quality assurance/quality control necessary for the field analysis of lead and arsenic concentrations in surface soils include:

- Calibration of the XRF analyzer each day in the field (EPA 2007a), and as needed if air moisture changes during the day (e.g., changes in fog or light precipitation events)

- Instrument calibration using fundamental parameters determined by the manufacturer

- Measurement of the site-specific calibration standards each day (empirical calibration) (see further discussion above in Data Needs) 
- Measurement of the standard reference material each day

- Replicate measurements at each sampling location (number of replicates to be determined during the optimization study)

These measurements will demonstrate the variability of the XRF analyzer's performance throughout the field study. The results will determine the instrument's lower level of detection as well as the accuracy and precision of the sample measurements.

The XRF results will be reviewed, verified, and validated. The procedures for these steps will be based on EPA functional guidelines and the Hanford Analytical Services Quality Requirements Documents (HASQARD) (DOE-RL 2007). The validation procedures will be modified from existing protocols for field screening tools and XRF measurements. Members of HASQARD will review the procedures prior to data evaluation for the pilot study.

\subsection{Data Assessment for Final Report}

The final report for the pilot study will evaluate and discuss the results of the lead and arsenic concentrations within each pilot study decision unit to meet the purpose of the pilot study. The raw data from the field activities will be available. Heat maps will show the distribution and extent of lead and arsenic concentrations across the pilot study decision unit. The results will also be displayed over the 1943 and current aerial imagery to infer if there are agricultural areas rather than orchards in the decision units. This information will support recommendations for the decision units to be evaluated further in the RI/FS. Statistical analyses of the XRF results will support recommendations for the size of the decision unit (acreage), and the number of samples to take per decision unit (based on variability and statistical confidence for evaluation against a screening level). The data assessment will be used to make recommendations for the sampling and analytical methods for the RI/FS.

\subsection{References}

Delistraty D and J Yokel. 2011. "Ecotoxicological Study of Arsenic and Lead Contaminated Soils in Former Orchards at the Hanford Site, USA.” Environmental Toxicology DOI 10.1002/tox.20768.

DOE-RL (U.S. Department of Energy-Richland Operations Office). 2007. Hanford Analytical Services Quality Assurance Requirements Documents. DOE/RL-96-68, 2007, Rev. 3, Volumes 1, 2, 3, and 4. Richland, Washington.

DOE-RL (U.S. Department of Energy-Richland Operations Office). 2013. Remedial Investigation/Feasibility Study Work Plan to Evaluate the 100 OL-1 Operable Unit Pre Hanford Orchard Lands. DOE/RL-2012-64, Draft A. Richland, Washington.

EPA (U.S. Environmental Protection Agency). 2002. Guidance for Choosing a Sampling Design for Environmental Data Collection, QA/G-5S, Peer Review Draft. Office of Environmental Information, Washington, D.C. 
DOE/RL-2014-38

Revision 0

PNNL-23471

EPA (U.S. Environmental Protection Agency). 2007a. Method 6200: Field Portable X-ray

Fluorescence Spectrometry for the Determination of Elemental Concentrations in Soil and Sediment.

Office of Solid Waste and Emergency Response, Washington, D.C.

EPA (U.S. Environmental Protection Agency). 2007b. Test Methods for Evaluating Solid Waste:

Physical/Chemical Methods. SW-846, Third Edition, Final Update IV-B, as amended, Office of Solid Waste and Emergency Response, Washington, D.C.

EPA (U.S. Environmental Protection Agency). 2011. Field X-ray Fluorescence Measurement. Science and Ecosystem Support Division, Athens, Georgia.

Matzke BD, JE Wilson, LL Nuffer, ST Dowson, JE Hathaway, NL Hassig, LH Sego, CJ Murray, BA Pulsipher, B Roberts, and S McKenna. 2010. Visual Sample Plan Version 6.0 User's Guide. PNNL 19915, Pacific Northwest National Laboratory, Richland, Washington. Available at: http://vsp.pnnl.gov/docs/PNNL\%2019915.pdf.

Yokel J and DA Delistraty. 2003. “Arsenic, Lead, and Other Trace Elements in Soils Contaminated with Pesticide Residues at the Hanford Site (USA).” Environmental Toxicology 18:104-114. 
DOE/RL-2014-38

Revision 0

PNNL-23471

\subsection{Images of the Pilot Study Decision Units}

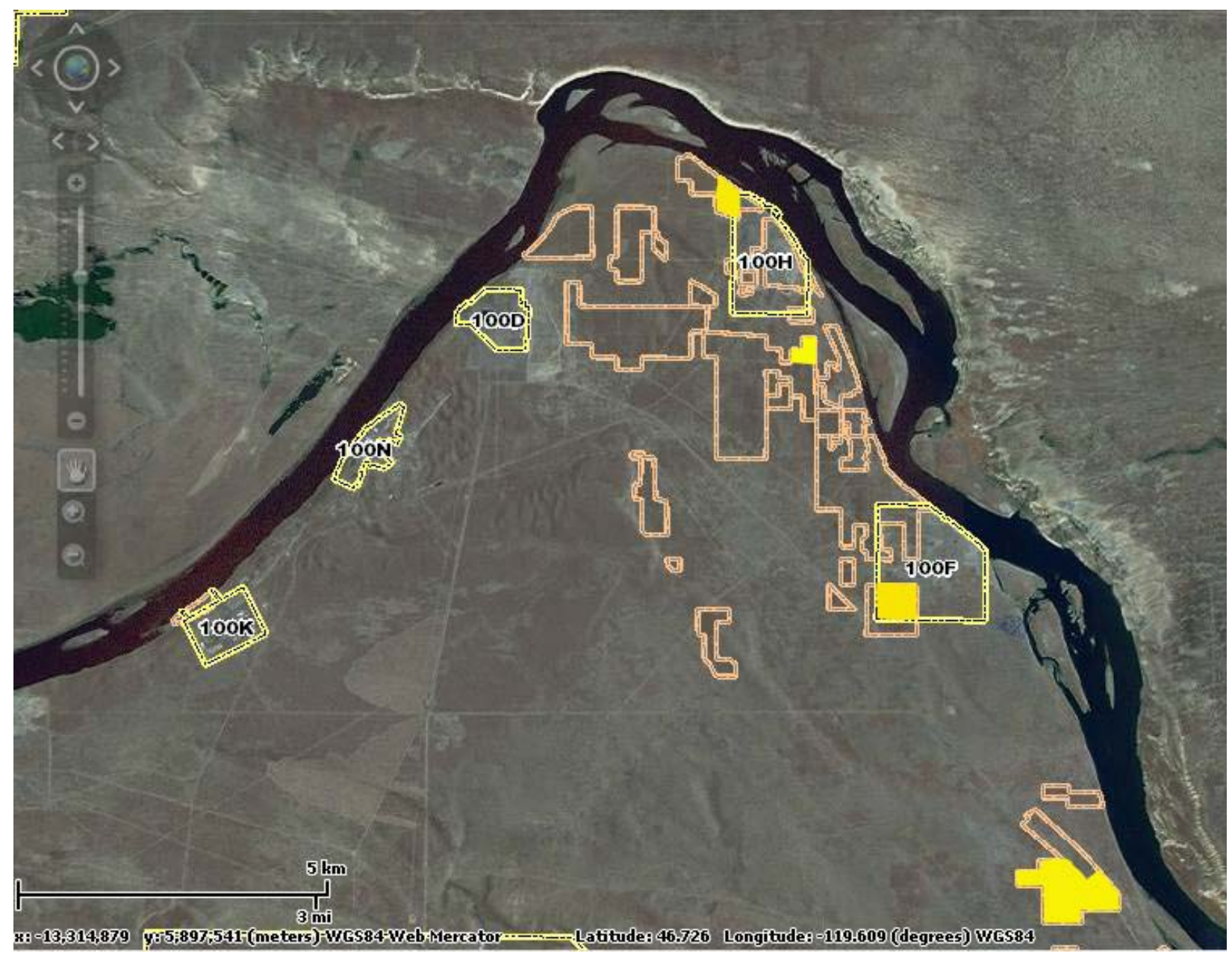

Figure 1. Pilot Study Decision Units (yellow fill) within the 100-OL-1 Operable Unit 
DOE/RL-2014-38

Revision 0

PNNL-23471

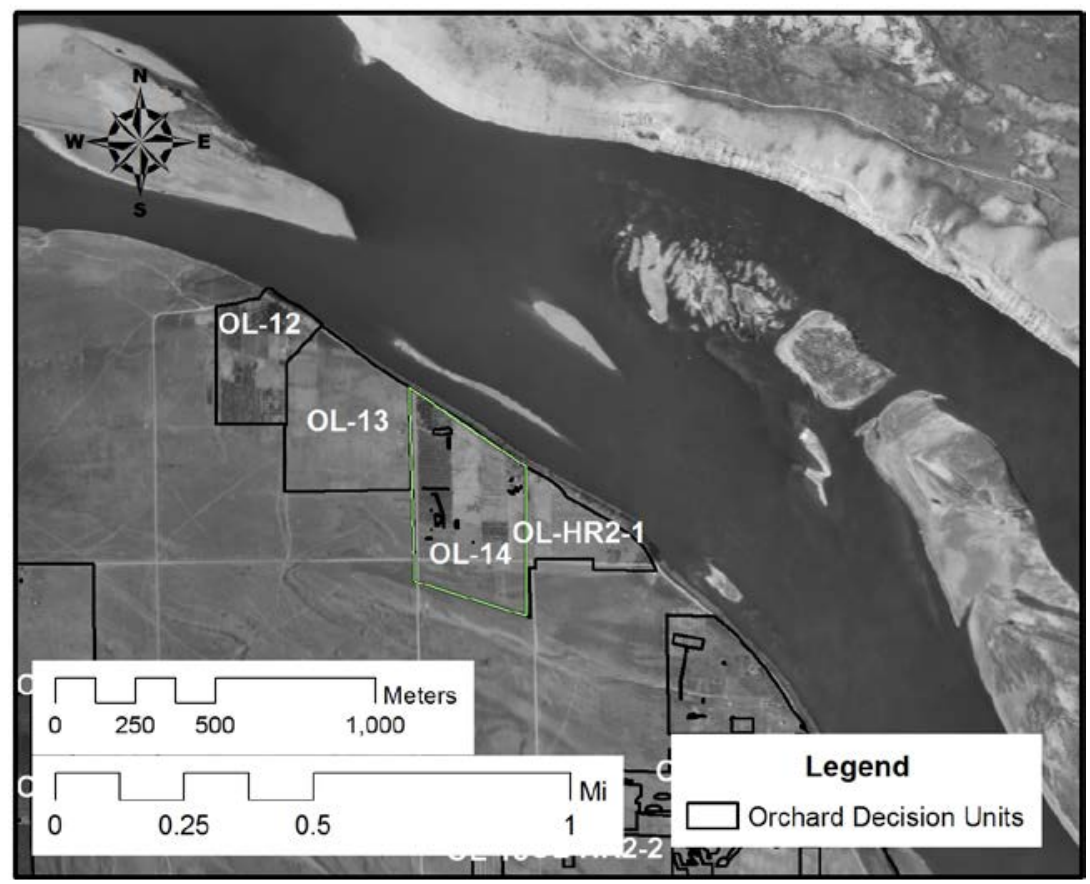

Figure 2. 1943 Aerial Imagery with OL-14 Decision Unit (green outline)



Figure 3. Current Aerial Imagery with OL-14 Decision Unit and Select Locations for Sampling (yellow dots) 
DOE/RL-2014-38

Revision 0

PNNL-23471

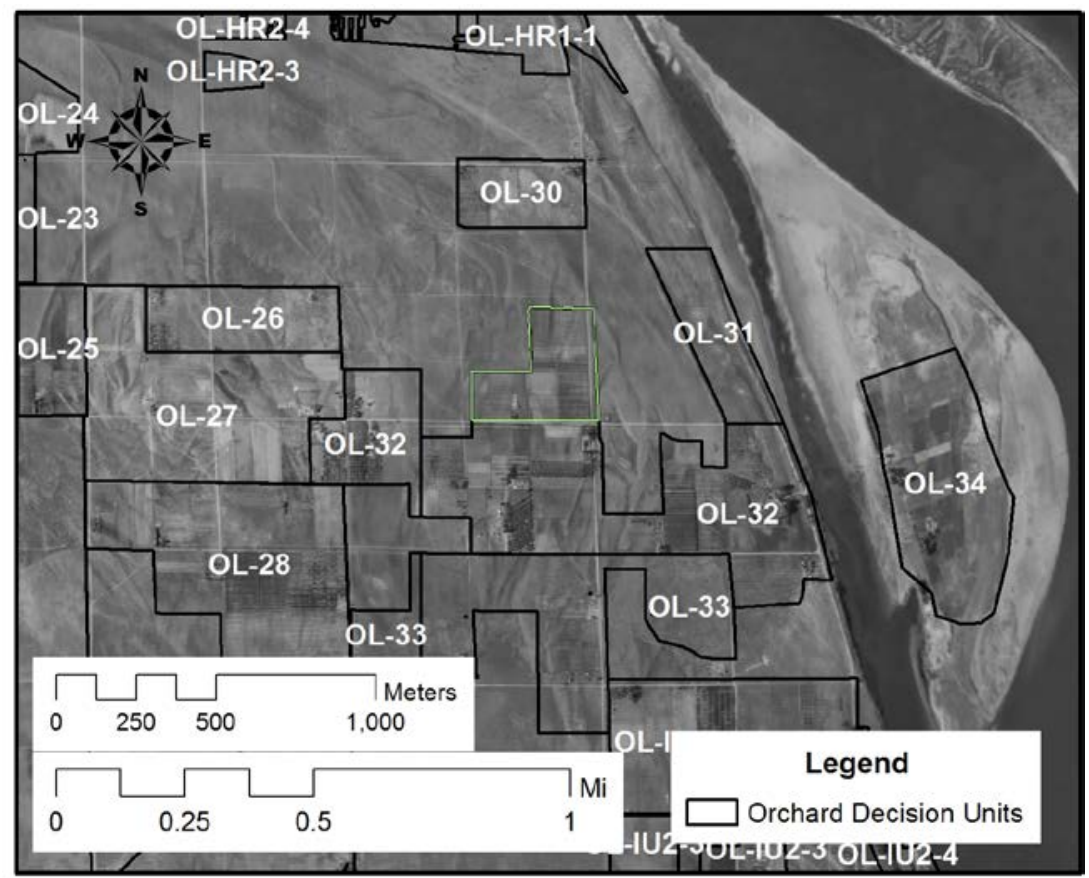

Figure 4. 1943 Aerial Imagery with OL-32 Decision Unit (green outline)



Figure 5. Current Aerial Imagery with OL-32 Decision Unit and Select Locations for Sampling (yellow dots) 
DOE/RL-2014-38

Revision 0

PNNL-23471

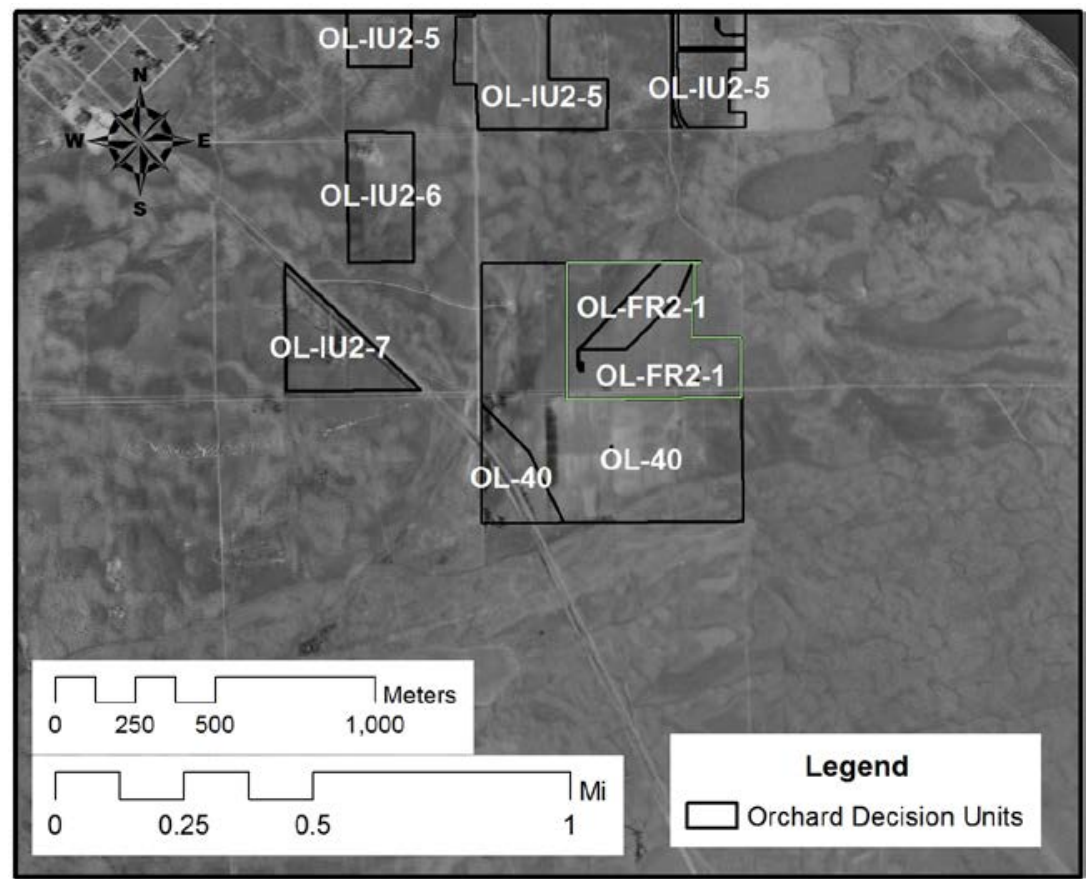

Figure 6. 1943 Aerial Imagery with OL-FR2-1 Decision Unit (green outline)

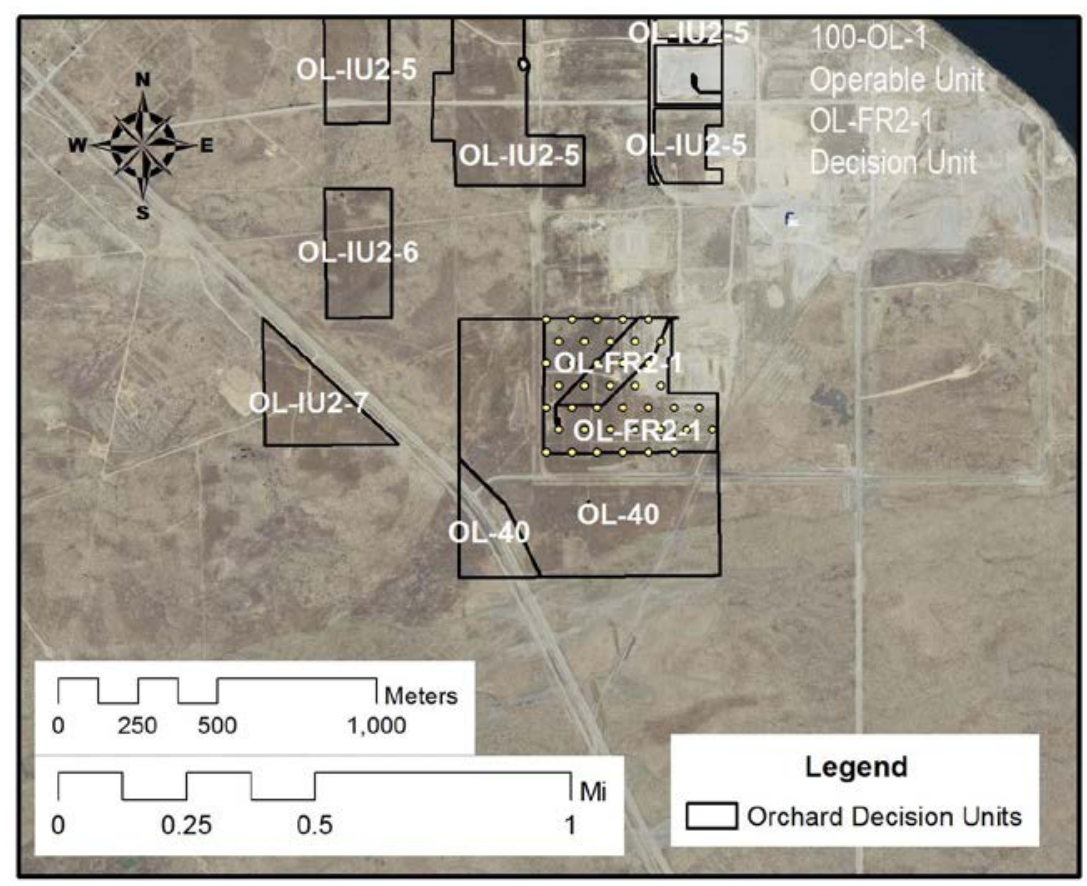

Figure 7. Current Aerial Imagery with OL-FR2-1 Decision Unit and Select Locations for Sampling (yellow dots) 
DOE/RL-2014-38

Revision 0

PNNL-23471

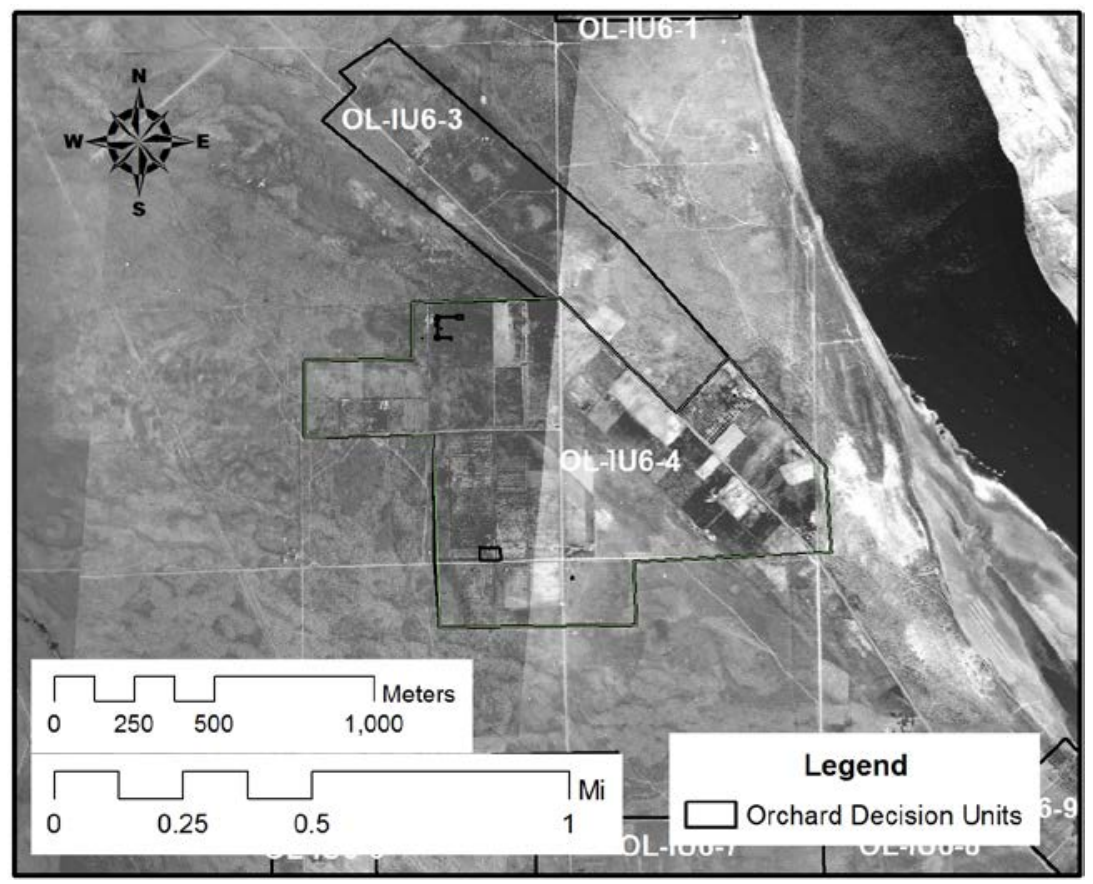

Figure 8. 1943 Aerial Imagery with OL-IU6-4 Decision Unit (green outline)

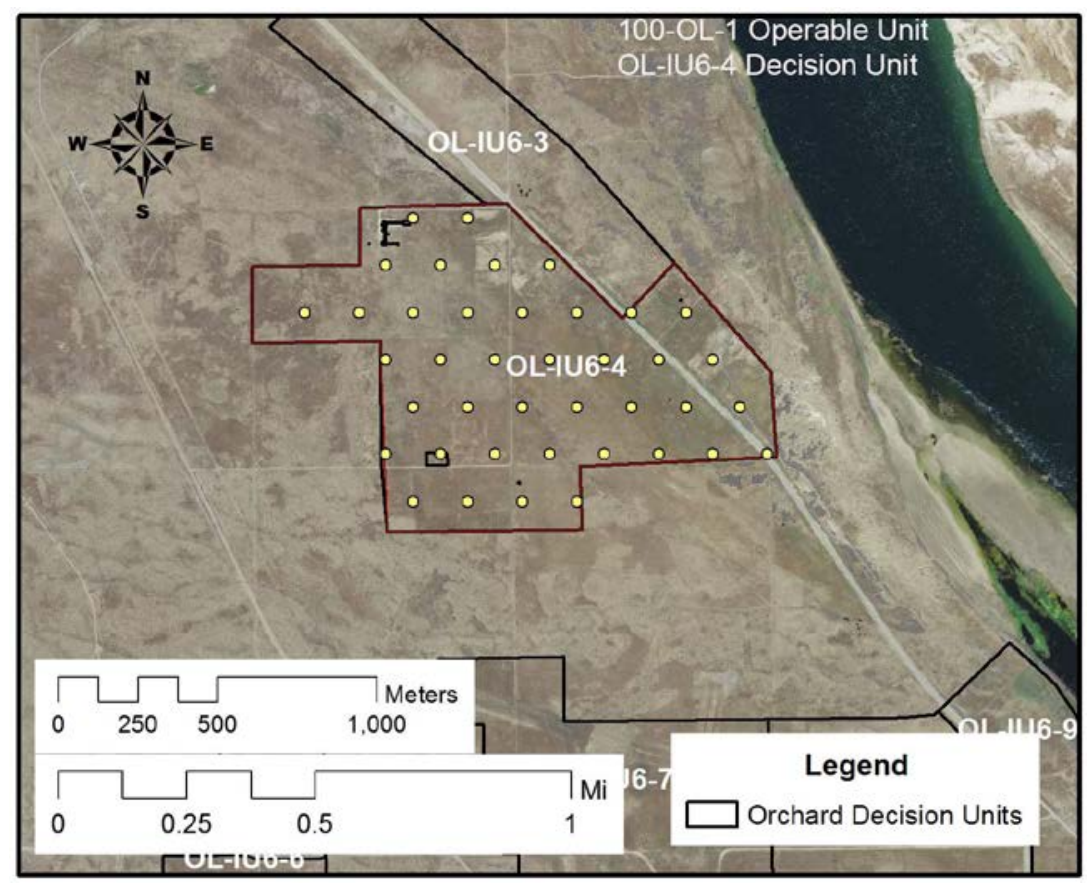

Figure 9. Current Aerial Imagery with OL-IU6-4 Decision Unit and Select Locations for Sampling (yellow dots) 